\title{
Herbal Medicines in Treating Typhoid Fever: Correlation of Information in Indonesia News Portals and Research Results
}

\author{
$1^{\text {st }}$ A P Rahayu \\ Pharmacy Department of Universitas \\ Muhammadiyah Bandung \\ Bandung, Indonesia \\ anis.puji.rahayu@hotmail.com
}

\author{
$2^{\text {nd }}$ T D A Tugon \\ Pharmacy Department of Universitas \\ Muhammadiyah Bandung \\ Bandung, Indonesia
}

\begin{abstract}
Typhoid fever is a disease with a high prevalence in Indonesia. This disease is caused by a species of pathogenic bacteria called Salmonella typhi. The case of handling typhoid fever becomes more complicated when many cases of Salmonella typhi's resistance to antibiotics are found as the first line of treatment. An alternative treatment is needed to handle the resistance cases, one of them by using herbs. Indonesian people often use alternative medicine in the form of herbs. This study aims to see the correlation of news coverage in electronic media related to herbal medicine information in curing typhoid fever with the results of research that has been done. The research method used was an observation of electronic media with news related to typhoid fever in Bahasa Indonesia and reviews of scientific reports that showed antibacterial activity against $S$. typhi. The results showed that 17 herbs were informed in the media as anti-typhoid fever drugs, 11 of them $(64.7 \%)$ had been studied as having antibacterial activity against $S$. typhi.
\end{abstract}

\section{Keywords—Herbal Medicien, Typhoid, Indonesia}

\section{INTRODUCTION}

Typhoid fever has become an endemic disease in Indonesia with a prevalence rate of $1.7 \%$ [1]. This disease is an infectious disease mainly caused by Salmonella enterica serotype typhi ( $S$. typhi) [2]. Patients with typhoid fever have the main symptoms of fever. Initially, the fever feels mild and faint then every day is increasing accompanied by headaches, diarrhea or constipation, abdominal pain, muscle aches, anorexia. [3], [4]. Studies in the Jakarta area showcases typhoid fever per 100,000 people per year reaching 148.7 (ages 2-4 years), 180.3 (ages 5-15 years), and 51.2 (ages $>16$ years). Without the right treatments, the death rate from typhoid fever ranges from $10-30 \%$ and decreases by $1-4 \%$ through proper treatment. [5]. The high incidence of fever causes many losses including reducing work productivity, increasing student absence from school, and spending a lot of money on treatment. [1].

Treatment of typhoid fever is carried out by using antibiotics that are able to specifically target S. typhi so that the bacteria stop replicating. Eradication of $S$. typhi to $90 \%$ is important to prevent relapse and fecal carriage [2]. The first line antibiotics for typhoid fever are chloramphenicol, ampicillin, or amoxicillin, followed by co-trimoxazole. Whereas the second line of therapy uses ceftriaxone, cefixime, and quinolone. [3]. Irrational use of antibiotics and noncompliance of patients in taking drugs cause $\quad S$. typhi bacteria resistance to existing antibiotics. Cases of early resistance to chloramphenicol-resistant typhoid were reported in 1972. At this stage, microbes are still sensitive to co-trimoxazole and amoxicillin or ampicillin. But in the 1980s and 1990s occurred a typhoid outbreak that was resistant to chloramphenicol, cotrimoxazole, ampicillin, and amoxicillin. S. typhi's resistance to the four antibiotics is called multi-drug resistant. [2], [4]. The choice of antibiotic therapy in the case of multidrug resistance is fluoroquinolones and thirdgeneration cephalosporins [6]. But now there have been reported many cases of decreased susceptibility to these antimicrobials [2], [6].

Microbial resistance to antibiotics causes many disadvantages including the length of therapy that must be carried out by patients and the increase in cases of death due to infections that are not handled properly [7]. Therefore, efforts are needed to minimize microbial resistance to antibiotics. One way that can be taken to minimize microbial resistance is the use of herbs with antibiotics [8] or even the use of herbs individually. Besides Indonesia is a tropical country with a high biodiversity wealth that must be managed, researched, and utilized to improve the quality of life of the people.

Indonesian people have long used herbs to deal with everyday health complaints and treat various diseases, one of which is typhoid fever. Along with ethnopharmacology studies related to typhoid fever, researchers in Indonesia starting in the 20th century vigorously conducted testing of herbs suspected of having anti-microbial activity against $\mathrm{S}$. 
typhi. These tests can be accessed easily through googlescholars. However, information from research results and scientific studies is not necessarily well conveyed to the general public who tend to prefer reading information through the website [9]. This study aims to look at the correlation of news coverage on herbal related information on curing typhoid fever with the results of research on antimicrobial activity against $S$. typhi that has been done.

\section{METHODS}

The research method used was observation of news portal website with news related to typhoid fever from January 2016 to April 2020 and reviews of scientific publications on Google Scholars that show antibacterial activity against $S$. typhi. The search keywords for information on the website are 'Pengobatan herbal tipes' and 'Obat alami tipes'. While the keywords on Google Scholars are 'antimicrobial activity', 'medicinal plants', 'herbs', 'typhoid fever', and 'Salmonella typhi'.

\section{RESULT AND DISCUSSION}

\section{A. Result}

Herbal related information that can be used to treat typhoid fever is obtained from 24 websites. 17 herbs that are informed to treat typhoid fever as listed in Table 1 . The most frequently informed herbs are basil and garlic leaves with the frequency of citation in the news portal of 16.67 , followed by apple cider vinegar, cloves, and honey with successive values of $15.38 ; 14.10$; and 14.10 . Of the 17 herbs identified listed in the news portal, 5 herbs were not proven to have antibacterial activity against $S$. typhi, and 1 herbal namely guava flowers was not found related references.

B. Discussion
From January 2016 to April 2020, 24 Indonesian language websites displayed information related to herbal medicines for typhoid fever therapy. Each website lists herbs that are different, but there are 4 (four) types of herbs that dominate (about 60\%) information on the website, i.e. basil leaves, garlic, apple cider vinegar, and cloves. These four herbs have been widely studied and proven to have activity against $S$. typhi [10]-[16]. Almost all herbs that are proven to have antibacterial activity against $S$. typhi have flavonoids. Flavonoid compounds work by inhibiting the enzyme peptidoglycan transpeptidase so that the formation of cell walls is disrupted and cells become lysis [14].

Herbs that do not have antibacterial activity against $\mathrm{S}$. typhi in this study are honey, worm extracts, Sambiloto leaves, castor leaves, mangosteen skin, and soursop leaves. While the antibacterial activity of guava flowers has never been determined. This is an opportunity for researchers to prove the benefits of guava flowers as an alternative treatment for typhoid fever. This related information should be conveyed openly on the website so that the public gets clear information and does not feel disadvantaged. This is because access to health information through the website or news portal is now more preferred by the public [9]. The tendency of people to choose a health news portal is based on the consideration of ease of access and lower costs [9].

Apart from the herbs in Table 1, there are still a lot of herbs that have been studied but do not appear in the news portal. These herbs include sapodilla manila, Gatal leaves, Kenikir leaves, guava leaves, langsat skin, banana peels, and hundreds of other investigated herbs. Therefore, it is necessary to write research results in electronic mass media to facilitate people in accessing the information on herbal medicines that have been proved as anti-S. typhi.

TABLE I SEARCH RESULTS RELATED TO HERBAL INFORMATION THAT CAN BE USED TO TREAT TYPHOID FEVER.

\begin{tabular}{|c|c|c|c|c|c|}
\hline No. & $\begin{array}{c}\text { Vernacular/ Indonesia } \\
\text { name (International } \\
\text { name) }\end{array}$ & Species & $\begin{array}{c}\text { Frequency of } \\
\text { citation on news } \\
\text { portal }\end{array}$ & Identified substances & Pharmacological Data \\
\hline 1 & $\begin{array}{l}\text { Daun basil (basil } \\
\text { leaves) }\end{array}$ & $\begin{array}{l}\text { Ocimum basilicum } \\
\mathrm{L} .\end{array}$ & 16.67 & $\begin{array}{l}\text { Essential oils (linalool, estragol and } \\
\text { eugenol), } \\
\text { tannins, flavonoids, [15], [16] }\end{array}$ & $\begin{array}{l}\text { Antibacterial activity on } \\
\text { Salmonella typhi [16] }\end{array}$ \\
\hline 2 & Bawang putih (garlic) & Allium sativum & 16.67 & Allin, allicin [10] & $\begin{array}{l}\text { Antibacterial activity on } \\
\text { Salmonella typhi }[10]\end{array}$ \\
\hline 3 & $\begin{array}{l}\text { Cuka sari apel } \\
\text { (apple cider vinegar) }\end{array}$ & & 15.38 & $\begin{array}{l}\text { Acetic acid, B1, B vitamin, amino acids, } \\
\text { flavonoids, pectin, potassium, magnesium } \\
\text { [11] }\end{array}$ & $\begin{array}{l}\text { Antibacterial activity on } \\
\text { Salmonella typhi }[11]\end{array}$ \\
\hline 4 & Cengkeh (cloves) & $\begin{array}{l}\text { Syzygium } \\
\text { aromaticum } \mathrm{L},\end{array}$ & 14.10 & $\begin{array}{l}\text { Essesntial oils (eugenol), tannins, } \\
\text { flavonoids, [15], fatty acids (linoleic and } \\
\text { oleic), stearic and palmitic acids, tocols, } \\
\text { [12], caryophyllene, eugenol acetate, [13] }\end{array}$ & $\begin{array}{l}\text { Activity of the essential oils } \\
\text { against Salmonella enterica } \\
\text { serovar typhi [13]; [17] }\end{array}$ \\
\hline 5 & Madu (honey) & & 8.97 & & $\begin{array}{l}\text { No antibacterial activity on } S \text {. } \\
\text { typhi }[18]\end{array}$ \\
\hline 6 & Kunyit (turmeric) & Curcuma longa & 5.13 & $\begin{array}{l}\text { Alkaloid, tannin, flavonoid, curcumin, } \\
\text { glicoside, proteins, mineral [19] }\end{array}$ & $\begin{array}{l}\text { Antibacterial activity on } \\
\text { Salmonella typhi [19] }\end{array}$ \\
\hline 7 & Ekstrak cacing tanah & $\begin{array}{l}\text { Lumbricus } \\
\text { rubellus }\end{array}$ & 5.13 & & $\begin{array}{l}\text { No antibacterial activity on } S \text {. } \\
\text { typhi [20] }\end{array}$ \\
\hline 8 & Cranberi (cranberry) & $\begin{array}{l}\text { Vaccinium } \\
\text { macrocarpon }\end{array}$ & 2.56 & $\begin{array}{l}\text { Proanthocyanidin, phenolic compounds } \\
\text { (flavone, quercetine, naringenin) [21] }\end{array}$ & $\begin{array}{l}\text { Antibacterial activity on } \\
\text { Salmonella typhimurium [21] }\end{array}$ \\
\hline 9 & Lemon (lemon) & Citrus limon & 2.56 & & $\begin{array}{l}\text { No antibacterial activity on S. } \\
\text { typhimurium [22] }\end{array}$ \\
\hline 10 & $\begin{array}{l}\text { Bunga jambu biji } \\
\text { (guava flowers) }\end{array}$ & $\begin{array}{l}\text { Psidium guajava } \\
\text { L. }\end{array}$ & 2.56 & & \\
\hline 11 & Kismis (raisins) & Vitis vinifera & 2.56 & Polyphenolic compounds [23] & $\begin{array}{l}\text { Little antibacterial activity on } \\
\text { S. typhimurium [23] }\end{array}$ \\
\hline 12 & $\begin{array}{l}\text { Temulawak } \\
\text { (Curcuma) }\end{array}$ & $\begin{array}{l}\text { Curcuma } \\
\text { xanthorrhiza }\end{array}$ & 1.28 & Xanthorrhizol [24] & $\begin{array}{l}\text { Antibacterial activity on } \\
\text { Salmonella typhimurium }[24]\end{array}$ \\
\hline
\end{tabular}




\begin{tabular}{|c|l|l|c|l|l|}
\hline No. & $\begin{array}{l}\text { Vernacular/ Indonesia } \\
\text { name (International } \\
\text { name) }\end{array}$ & \multicolumn{1}{|c|}{ Species } & $\begin{array}{c}\text { Frequency of } \\
\text { citation on news } \\
\text { portal }\end{array}$ & Identified substances & \multicolumn{1}{c|}{ Pharmacological Data } \\
\hline 13 & $\begin{array}{l}\text { Daun sambiloto } \\
\text { (Sambiloto leaves) }\end{array}$ & $\begin{array}{l}\text { Andrographis } \\
\text { paniculata }\end{array}$ & 1.28 & & $\begin{array}{l}\text { Antibacterial activity on } S . \\
\text { typhimurium }[25]\end{array}$ \\
\hline 14 & $\begin{array}{l}\text { Daun jarak merah } \\
\text { (castor leaves) }\end{array}$ & $\begin{array}{l}\text { Jatropha } \\
\text { gossypiifolia }\end{array}$ & 1.28 & Terpenoids and lignoid [26] & $\begin{array}{l}\text { Antibacterial activity on } S . \\
\text { typhi [26] }\end{array}$ \\
\hline 15 & $\begin{array}{l}\text { Kulit manggis } \\
\text { (mangosteen skin) }\end{array}$ & $\begin{array}{l}\text { Garcinia } \\
\text { mangostana L. }\end{array}$ & 1.28 & & $\begin{array}{l}\text { No antibacterial activity on } S . \\
\text { typhimurium [27] }\end{array}$ \\
\hline 16 & $\begin{array}{l}\text { Daun sirsak (soursop } \\
\text { leaves) }\end{array}$ & Annona muricata & 1.28 & $\begin{array}{l}\text { No antibacterial activity on } S . \\
\text { typhi [28] }\end{array}$ & $\begin{array}{l}\text { Antibacterial activity on } S . \\
\text { typhi }[14]\end{array}$ \\
\hline 17 & Daun keji beling & $\begin{array}{l}\text { Strobilanthes } \\
\text { crispa }\end{array}$ & 1.28 & Flavonoids [14] & \\
\hline \multicolumn{2}{|r|}{ TOTAL } & 100 & & & \\
\hline
\end{tabular}

\section{CONCLUSION}

As many as $65 \%$ of herbs mentioned in the news portal have been investigated to have antibacterial activity against S. typhi.

\section{REFERENCES}

[1] I. Elisabeth Purba, T. Wandra, N. Nugrahini, S. Nawawi, and N. Kandun, "Program Pengendalian Demam Tifoid di Indonesia: Tantangan dan Peluang," Media Penelit. dan Pengemb. Kesehat., vol. 26, no. 2, pp. 99-108, 2016.

[2] H. Trawinski, S. Wendt, N. Lippmann, S. Heinitz, A. Von Braun, and C. Lübbert, "Typhoid and paratyphoid fever," $Z$. Gastroenterol., vol. 58, no. 2, pp. 160-170, 2020.

[3] S. F. Supari, "Keputusan Menteri Kesehatan Republik Indonesia No. 364 tentang Pedoman Pengendalian Demam Tifoid," Menteri Kesehatan Republik Indonesia. p. 41, 2006.

[4] F. M. Sánchez-Vargas, M. A. Abu-El-Haija, and O. G. GómezDuarte, "Salmonella infections: An update on epidemiology, management, and prevention," Travel Med. Infect. Dis., vol. 9, no. 6, pp. 263-277, 2011.

[5] S. Alba et al., "Risk factors of typhoid infection in the Indonesian archipelago," PLoS One, vol. 11, no. 6, pp. 1-14, 2016.

[6] T. Butler, "Treatment of typhoid fever in the 21 st century: promises and shortcomings," Clin. Microbiol. Infect., vol. 17, no. 7, pp. 959-963, 2011

[7] A. Geissler, P. Gerbeaux, I. Granier, P. Blanc, K. Facon, and J. Durand-Gasselin, "Rational use of antibiotics in the intensive care unit: Impact on microbial resistance and costs," Intensive Care Med., vol. 29, no. 1, pp. 49-54, 2003.

[8] K. Abascal and E. Yarnell, "Herbs and drug resistance: Part 1 Herbs and microbial resistance to antibiotics," Altern. Complement. Ther., vol. 8, no. 4, pp. 237-241, 2002.

[9] Siswanta, "Informasi Kesehatan di Media Online," Inf. Kesehat. di Media Online, vol. 13, pp. 210-223, 2015.

[10] L. P. I. V. Vinenthy, N. Habibah, and I. G. A. S. Dhyanaputri, "Uji Daya Hambat Perasan Bawang Putih terhadap Pertumbuhan Salmonella typhi," J. Kesehat., vol. 10, no. 3, p. 354, 2019.

[11] T. S. A. . Pratama R.I., Husin U.A., "Prosiding Pendidikan Dokter ISSN: 2460-657X,” pp. 601-607, 2015.

[12] M. F. Ramadan, M. M. S. Asker, and M. Tadros, "Lipid profile, antiradical power and antimicrobial properties of Syzygium aromaticum oil," Grasas y Aceites, vol. 64, no. 5, pp. 509-520, 2013.

[13] K. Singletary, "Clove: Overview of potential health benefits," Nutr. Today, vol. 49, no. 4, pp. 207-224, 2014.

[14] M. Benigna, "Uji Daya Hambat Ekstrak Daun Keji Beling (Srobilanthes Crispa B1.) terhadap Pertumbuhan Bakteri Salmonella typhi Secara In Vitro," 2015.

[15] G. G. F. Nascimento, J. Locatelli, P. C. Freitas, G. L. Silva, and U. M. De Piracicaba, "ANTIBACTERIAL ACTIVITY OF PLANT EXTRACTS AND PHYTOCHEMICALS ON ANTIBIOTIC-," pp. 247-256, 2000.

[16] M. Kristiani, S. L. Ramayani, K. Yunita, and M. Saputri, "Formulasi dan Uji Aktivitas Nanoemulsi Minyak Atsiri Daun Kemangi (Ocimum basilicum L.) Terhadap Salmonella typhii,"

J. Farm. Indones., vol. 16, no. 1, pp. 14-23, 2019.

[17]

K. P. Devi, S. A. Nisha, R. Sakthivel, and S. K. Pandian, "Eugenol (an essential oil of clove) acts as an antibacterial agent against Salmonella typhi by disrupting the cellular membrane," J. Ethnopharmacol., vol. 130, no. 1, pp. 107-115, 2010. G. G. Alhadz, "AKTIVITAS ANTIBAKTERI MADU EKSTRAK DAUN PEPAYA ( Carica Papaya L .), DAUN KEMANGI ( Ocimum sanctum L . ), DAN RIMPANG TEMU IRENG ( Curcuma aeruginosa Roxb .) TERHADAP PERTUMBUHAN Salmonella typhimurium SKRIPSI Oleh Ghias Ghifari Alhadz," 2019.

[19] L. N. B. Ika, "Uji Efektifitas Daya Hambat Ekstrak Rimpang Kunyit (Curcuma longa) Terhdap Pertumbuhan Bakteri Salmonella typhi dengan Metode Disc Diffusion Secara In Vitro."

[20] M. A.P. Pratomo, A. Susanto, "Uji Daya Hambat Ekstrak Cacing Tanah (Lumbricus rubellus) terhadap Pertumbuhan Bakteri Salmonella typhi dengan Menggunakan Metode Difusi."

[21] V. C. H. Wu, X. Qiu, A. Bushway, and L. Harper, "Antibacterial effects of American cranberry (Vaccinium macrocarpon) concentrate on foodborne pathogens," LWT - Food Sci. Technol., vol. 41, no. 10, pp. 1834-1841, 2008.

[22] K. A. Hammer, C. F. Carson, and T. V. Riley, "Antimicrobial activity of essential oils and other plant extractsThe antimicrobial activity of plant oils and extracts has been recognized for many years. However, few investigations have compared large numbers of oils and extracts using methods that are," J. Appl. Microbiol., vol. 86, no. 6, pp. 985-990, 1999.

[23] Y. M. Abouzeed et al., "Identification of phenolic compounds, antibacterial and antioxidant activities of raisin extracts," Open Vet. J., vol. 8, no. 4, pp. 479-484, 2018.

[24] Y. L. Lee, J. S. Shim, Y. Rukayadi, and J. K. Hwang, "Antibacterial activity of xanthorrhizol isolated from Curcuma xanthorrhiza Roxb. against foodborne pathogens," J. Food Prot., vol. 71, no. 9, pp. 1926-1930, 2008.

[25] B. S. N. U. S. Mishra, A. Mishra, R. Kumari, P. N. Murthy, "Antibacterial Activity of Ethanol Extract of Andrographis paniculata," Indian J. Pharm. Sci., vol. 71, no. 4, pp. 436-438, 2009.

[26] J. Félix-Silva, R. B. Giordani, A. A. Da Silva-Jr, S. M. Zucolotto, and M. D. F. Fernandes-Pedrosa, "Jatropha gossypiifolia L. (Euphorbiaceae): A review of traditional uses, phytochemistry, pharmacology, and toxicology of this medicinal plant," Evidence-based Complement. Altern. Med., vol. 2014, 2014.

[27] P. M. Poeloengan, "UJI AKTIVITAS ANTIBAKTERI EKSTRAK KULIT BUAH MANGGIS (Garcinia mangostana Linn)," Media Heal. Res. Dev., vol. 20, no. 2 Jun, pp. 65-69, 2012.

[28] R. P. APRIYUSLIM, "UJI AKTIVITAS ANTIBAKTERI EKSTRAK ETANOL DAUN SIRSAK ( Annona muricata L .) TERHADAP Salmonella typhi SECARA IN VITRO,” 2015. 